University of Nebraska - Lincoln

DigitalCommons@University of Nebraska - Lincoln

Management Department Faculty Publications

Management Department

$9-2009$

\title{
Measuring workplace spirituality in an Asian context
}

\author{
Pawinee Petchsawanga \\ University of the Thai Chamber of Commerce, Thailand, ppetchsawang@yahoo.com \\ Dennis Duchon \\ University of Nebraska-Lincoln, dduchon2@unl.edu
}

Follow this and additional works at: https://digitalcommons.unl.edu/managementfacpub

Part of the Management Sciences and Quantitative Methods Commons

Petchsawanga, Pawinee and Duchon, Dennis, "Measuring workplace spirituality in an Asian context" (2009). Management Department Faculty Publications. 93.

https://digitalcommons.unl.edu/managementfacpub/93

This Article is brought to you for free and open access by the Management Department at DigitalCommons@University of Nebraska - Lincoln. It has been accepted for inclusion in Management Department Faculty Publications by an authorized administrator of DigitalCommons@University of Nebraska - Lincoln. 
Published in Human Resource Development International 12:4 (September 2009), pp. 459-468;

doi: 10.1080/13678860903135912

Copyright (C 2009 Taylor \& Francis. Used by permission. http://www.informawor1d.com

\title{
Measuring workplace spirituality in an Asian context
}

\author{
Pawinee Petchsawang \\ Department of Human Resource Management, School of Business, University of the Thai Chamber \\ of Commerce, 126/1 Vibhavadee-Rangsit Road, Dindaeng, Bangkok 10400, Thailand. \\ Corresponding author: email ppetchsawang@yahoo.com
}

\section{Dennis Duchon}

Department of Management, College of Business Administration, University of Tennessee, 408 Stokely Management Center, 916 Volunteer Blvd. Knoxville, TN 3 7996-0545 USA

\begin{abstract}
This paper presents the development of a measure for workplace spirituality. Workplace spirituality is initially proposed to consists of five components, but confirmatory factor analysis (CF A) applied to data collected from employees from a large Thai company suggests a four-factor model: compassion, meaningful work, mindfulness and transcendence.
\end{abstract}

Keywords: workplace spirituality; measurement

People work with not only their hands, but also their hearts (spirit). It is when people work with their hearts or spirit that they find meaning and purpose, a kind of fulfillment that means the workplace can be a place where people can express their whole or entire selves and be fulfilled. Enabling the expression of human experience at its deepest, most spiritual level may not only reduce stress, conflict, and absenteeism, but also enhance work performance (Krahnke, Giacalone, and Jurkiewicz 2003).

Spirituality is seen increasingly as an important factor in the workplace (Neal 1997; Ashmos and Duchon 2000; Korac-Kakabadse, Kouzmin, and Kakabadse 2002; Krahnke, Giacalone, and Jurkiewicz 2003). Most of the research on spirituality at work has addressed a Western context, and, to date, nothing has approached the topic from an Eastern context. This paper examines workplace spirituality from an Eastern context because it reports the development of a measure relying on employees in a Thai organization.

An examination of spirituality at work is particularly applicable to the field of HRD because it goes beyond traditional cognitive and behavioral approaches to work and career development by addressing holistically learning and personal growth (Fenwick and Lange 1998) at a deeper level of human experience (Elliot and Turnbull 2005). Spirituality can shape individuals' behav- 
ior in a productive way from the inside out (Heaton, Schmidt-Wilk, and Travis 2004). Spirituality can guide employees in recognizing and understanding meaning in their lives, therefore benefiting their career development (Lips-Wiersma 2002). Finally, enhancing spirituality in workplace can be seen as an approach to organizational development by enabling the expression of values such as virtue, corporate citizenship, honesty and integrity (Petchsawang and Morris 2006). Thus, training programs that incorporate a spiritual dimension enable the development of the whole person, and not just the "head" and "hands." Developing our spiritual selves means expanding our consciousness so that we might see the world free of normal constraints (Howard 2002), and setting ourselves free to see more clearly thereby enables opportunities to creatively enrich our relationships with others.

\section{Workplace spirituality}

Dehler and Welsh $(2003,114)$ describe spirituality at work as "a search for meaning, deeper self-knowledge or transcendence to a higher level." Additionally, the sense of meaning and purpose serves as an inner source of energy that is then expressed outwardly as behavior. Tepper $(2003,183)$ defines spirituality as "the extent to which an individual is motivated to find sacred meaning and purpose to his or her existence," but notes, similar to an argument made by Mitroff and Denton (1999), that spirituality is not associated with religion, God or higher powers. Ashmos and Duchon (2000) address spirituality in the workplace both from the experience of individuals and the organization's work environment. They define a spiritual workplace as one that enables the individual's expression of an inner life by performing meaningful work in the context of a community. Moreover, they developed and tested one of the first scales purporting to measure spirituality in the workplace. Milliman, Czaplewski and Ferguson (2003) built on Ashmos and Duchon's (2000) work when they defined a spiritual workplace as one where individuals experienced meaningful work in a community. Milliman, Czaplewski and Ferguson (2003), however, proposed that the third element of spirituality in the workplace was an alignment with organizational values, not an inner life, and their notion of alignment is similar to that of Kinjerski and Skrypnek (2004).

There are other papers proposing definitions of spirituality. For example, Krishnakumar and Neck (2002) have proposed that the meaning of spirituality is idiosyncratic; however, their discussion includes notions of inner consciousness, and a search for meaning. Guillory (1997) also focuses on inner consciousness. He argues that spirituality is the domain of inner consciousness that expresses itself as a sense of "harmony, interconnectedness, and oneness." Similarly, Heaton, Schmidt-Wilk, and Travis (2004) define spirituality as inner consciousness, which is the state of "wakefulness as its essential nature, unmixed with images, thoughts, feelings, or any other objects of perception." Additionally, they suggest that people could achieve this inner consciousness state by practicing meditation regarding eastern religion traditions such as Buddhist meditation.

Mahoney and Graci (1999) have proposed that spirituality involves a sense of giving and service, a sense of connection (community), compassion and forgiveness, meaning, and morality. Delgado $(2005,159)$ argues that "the most common quality in descriptions of spirituality was transcendence, followed by meaning, mystery, animating or life-giving, connecting or unifying." Finally, Neck and Milliman (1994, 9-10) define workplace spirituality as "expressing a desire to find meaning and purpose in life," "a transcendent personal state," "living by inner truth 
to produce positive attitudes and relationships," and a belief of being connected to each other and desire to go beyond one's self-interest to contribution to society as a whole.

Although the definitions of spirituality at work vary, five themes seem often to surface: connection, compassion, mindfulness, meaningful work and transcendence. Therefore, the definition of workplace spirituality used in this research is as follows: workplace spirituality is about feeling connected with and having compassion toward others, experiencing a mindful inner consciousness in the pursuit of meaningful work and that enables transcendence.

We begin with the following five-factor definition of spirituality in the workplace. We use this definition to develop a measure of spirituality at work, and then we conduct an investigation into the psychometric properties of the measure. Two points need to be made about the definition of workplace spirituality. First, workplace spirituality is multi-dimensional. Second, each dimension or component has a connection to the other dimensions and cannot be seen in isolation.

\section{Measuring workplace spirituality}

\section{Dimension 1: Connection}

Connection is defined as one's experience of a deep sense of connection with other people and other people's work. This means one feels part of the community and can identify him/herself with the group's common purpose (Duchon and Plowman 2005). Connection is measured with three items from Kinjerski and Skrypnek (2006), and one item from Ashmos and Duchon (2000) (see Table 1).

\section{Dimension 2: Compassion}

Compassion is defined as a deep awareness of and sympathy for others (Twigg and Parayitam 2006) and a wish to relieve their suffering (Farlex 2007). Compassion leads to a responsibility for another who is less fortunate or suffering (Delgado 2005). Additionally, Delgado (2005) argues that it is a desire for mutual caring and supporting others. In this sense, a spiritual person generates an awareness of the needs of others and a desire to help other people (Ingersoll 2003). Measuring compassion presents a challenge as no complete, validated scale exits. Therefore, the items used to measure compassion were adapted from the work of McCormick (1994), Mohoney and Graci (1999), Ingersoll (2003), Delgado (2005), and Twigg and Parayitam (2006) (see Table 1).

\section{Dimension 3: Mindfulness}

Mindfulness is defined as a state of inner consciousness in which one is aware of one's thoughts and actions moment by moment. Mindfulness is about a person's mind being present, not wandering with past, future thoughts or other distractions. It is important to note that mindfulness is about acting with awareness; therefore, it stands in contrast to notions of "automatic pilot," acting without awareness (Baer, Smith and Allen 2004, 193). By being aware of their thoughts and actions in the present, people are better able to control their emotions and behaviors. Eight items from the "Mindful Attention Awareness Scale" (MAAS) (Brown and Ryan 2003) and one item from the "Freiburg Mindfulness Inventory" (FMI) (Walach et al. 2006) are used to measure mindfulness (see Table 1). 
Table 1. The items and psychometric properties of the workplace spirituality measure.

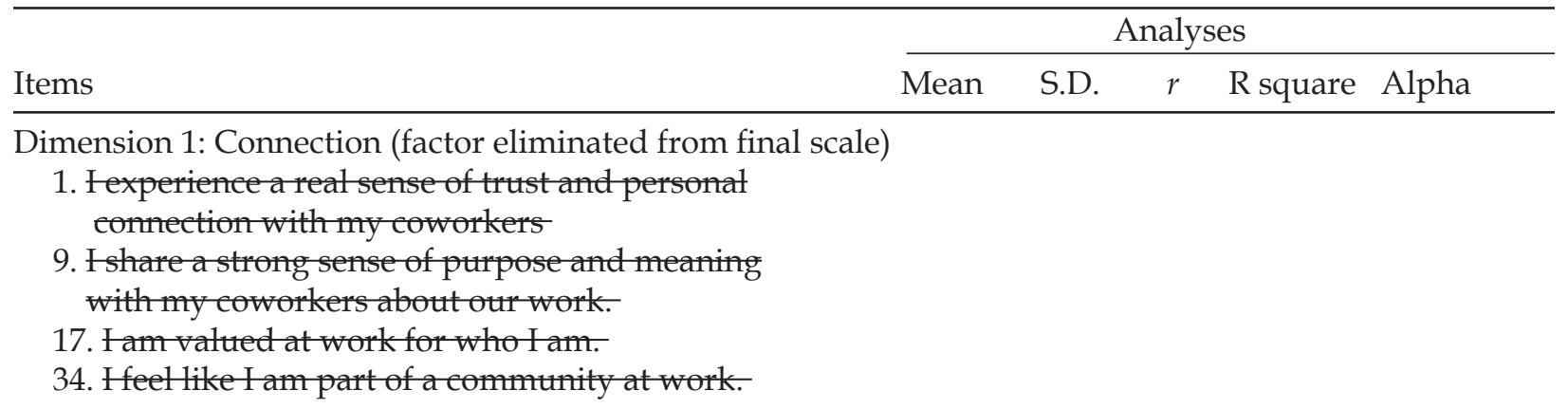

Dimension 2: Compassion

2. Isympathize with my coworkers' suffering.

7. Ido not eare about my coworker's' suffering.

11. I can easily put myself in other people's shoes.

15. It is not my responsibility to help my coworkers relieve their suffering.

18. I am aware of and sympathize with others.

21. I try to help my coworkers relieve their suffering.

31. I am aware of my coworkers' needs.

$\begin{array}{llll}4.31 & .57 & .61 & .37 \\ & & & \\ 4.07 & .55 & .68 & .46 \\ 3.84 & .68 & .42 & .18 \\ 3.94 & .60 & .52 & .28\end{array}$

Dimension 3: Mindfulness

3. Ifind it diffieult to stay foeused on what's happening in the present.

5. I find myself listening to someone with one ear, doing something else at the same time.

8. I do jobs or tasks automatically, without being aware of what I'm doing.

13. I find myself working without paying attention.

19. At work, I break or spill things because of carelessness, not paying attention, or thinking of something else.

20. I rush through work activities without being really attentive to them.

23. I go to the places on 'automatic pilot' and then wonder why I went there.

26. It seems I am working automatically without much awareness of what I'm doing.

29. In diffieult work situations, I ean pause negativethoughts or actions without immediately reacting

Dimension 4: Meaningful work

4. I experience joy in my work.

10. I do not know why I am working here.

22. I look forward to coming to work most days.

24. I believe others experience joy as a result of my work

25. My spirit is energized by my work.

28. I see a connection between my work and the larger social good of my community.

30. I understand what gives my work personal meaning

36. The work I do is connected to what I think

$\begin{array}{llll}4.17 \quad .95 & .57 \quad .33\end{array}$

$\begin{array}{llll}3.75 & 1.06 & .65 & .43\end{array}$

$\begin{array}{llll}3.65 & 1.05 & .65 & .42\end{array}$

$\begin{array}{llll}4.10 & .79 & .84 & .71\end{array}$

$\begin{array}{llll}3.93 & 1.00 & .58 & .33\end{array}$

$\begin{array}{llll}4.13 & .95 & .51 & .26\end{array}$

is important in life.

$\begin{array}{llll}4.08 & .69 & .64 & .41 \\ & & & \\ 3.42 & .78 & .52 & .27 \\ 3.56 & .70 & .45 & .20 \\ & & & \\ 3.85 & .71 & .72 & .52 \\ 4.00 & .76 & .61 & .37 \\ 4.38 & .65 & .65 & .42 \\ 4.07 & .71 & .55 & .31\end{array}$

.78

.79

(continued) 
Table 1. (Continued).

\begin{tabular}{|c|c|c|c|c|c|}
\hline \multirow[b]{2}{*}{ Items } & \multicolumn{4}{|c|}{ Analyses } & \multirow[b]{2}{*}{ Alpha } \\
\hline & Mean & S.D. & $r$ & R square & \\
\hline Dimension 5: Transcendence & & & & & .75 \\
\hline \multicolumn{6}{|l|}{$\begin{array}{l}\text { 6. My faith in a higher power/ universal intelligence } \\
\text { helps me cope with challenges at my work. }\end{array}$} \\
\hline $\begin{array}{l}\text { 12. At times, I experience an energy or vitality } \\
\text { at work that is difficult to describe. }\end{array}$ & 3.50 & .97 & .34 & .12 & \\
\hline $\begin{array}{l}\text { 14. I experience moments at work where } \\
\text { everything is blissful. }\end{array}$ & 3.90 & .73 & .67 & .45 & \\
\hline \multicolumn{6}{|l|}{ 16. Helieve in a higher power/universal intelligence. } \\
\hline \multicolumn{6}{|l|}{$\begin{array}{l}\text { 27. Hhave a relationship with a higher power/ } \\
\text { thiversal intelligenee. }\end{array}$} \\
\hline 32. At times, I experience happiness at work. & 4.21 & .73 & .78 & .61 & \\
\hline $\begin{array}{l}\text { 33. I have moments at work in which I have } \\
\text { no sense of time or space }\end{array}$ & 3.92 & .79 & .63 & .39 & \\
\hline $\begin{array}{l}\text { 35. At moments, I experience complete joy } \\
\text { and ecstasy at work. }\end{array}$ & 4.00 & .75 & .73 & .53 & \\
\hline 37. My spirituality gives me inner strength & & & & & \\
\hline to solve my work problems. & & & & & \\
\hline
\end{tabular}

$r$ is the correlation between the item and its underlying dimension.

$\mathrm{R}$ square is a proportion of variance accounted for its underlying dimension by the item.

Cronbach's alpha coefficient is computed for each dimension excluding the strikethrough items.

\section{Dimension 4: Meaningful work}

Meaningful work is defined as one's experience that his/her work is a significant and meaningful part to his/her life. Indeed, one feels that work has meaning for him/her beyond the material rewards (Duchon and Plowman 2005). Meaningful work also creates a sense of joy and energy at work (Duchon and Plowman 2005). In another sense, meaningful work answers the question of why one is in the workplace by acknowledging that his/her work helps him/her to express his/her inner self (Krishnakumar and Neck 2002, 156; Ashforth and Pratt 2003, 311). Meaningful work is measured using seven items from Ashmos and Duchon (2000) (see Table 1).

\section{Dimension 5: Transcendence}

In this paper, transcendence indicates a connection to higher power (Delaney 2005). It does not involve a feeling of being connected with God because this research is about spirituality, not religion. Transcendence is measured with five items from Kinjerski and Skrypnek (2006) and two items from Delaney (2005). Kinjerski and Skrypnek $(2006,12)$ describe a mystical experience dimension as "a positive state of energy or vitality, a sense of perfection, transcendence, and experiences of joy and bliss" (see Table 1).

\section{Measurement translation}

The questionnaire was created in English. It was translated into Thai by a panel that was expert in Thai language, and was back-translated into English to assure that the meanings of 
the items held up when crossing language and culture frontiers. The translation of the workplace spirituality measurement followed guidelines suggested by Maxwell (1996), Hambleton (2002), and Birbili (2000), which specify a three-stage process: (1) multiple-forward translation; (2) backtranslation; and (3) translation review by bilingual judges. After processing the three steps, 37 items remained in the questionnaire assessing workplace spirituality (see Table 1).

\section{Procedure and sample}

A large (3800+ employees) Thai company that specializes in food and bakery deliveries was selected for this study because it has a reputation for being well managed and efficient. A well-run company was selected for the following reason: if spirituality matters at work, it will most likely be observable in a successful work environment. Human resources staff assisted in the data collection, which required the distribution of a hard-copy questionnaire to 250 randomly chosen employees. Some 206 informants returned completed questionnaires to the HR office through company mail ( $82.4 \%$ response rate) and these informants were anonymous to the first author.

Table 1 presents the questionnaire items. Informants responded to these items using a fivepoint Likert-type scale where 1 = strongly disagree and 5 = strongly agree. The informants (65 males, 141 females) were, on average, between 21 and 30 years of age and had been working for the company 5.8 years. The informants, on average, had earned a high school diploma. The informants can be seen as typical of employees working in the food industry in Thailand.

\section{Scale analysis}

Confirmatory factor analysis (CF A) was employed to examine the five proposed dimensions of workplace spirituality: connection, compassion, mindfulness, meaningful work and transcendence. The analysis included specifying a measurement model, determining model identification, assessing normality distribution, estimating parameters in the model, assessing the model fit, and modifying the model fit. The initial measurement model consisted of five latent variables with their indicators: connection (four indicators), compassion (seven indicators), mindfulness (nine indicators), meaningful work (eight indicators) and transcendence (nine indicators). The variance for each variable was set at 1 and the covariances among all variables were drawn in order to test their intercorrelations in the first-order CF A model. Normality for the spirituality items was assessed. Skewness ranges from -1.268 to .336 and kurtosis ranges from -.988 to 5.06. Item number 2's non-normal distribution makes it a candidate for elimination from the scale.

The measurement model with 37 items initially showed a poor fit: $\chi^{2}=1428.69, d f=619, p=$ $.00, C F I=.64$, and RMSEA $=.08$. The model was then modified based on indicators such as regression weights, standardized regression weights $(r)$, squared multiple correlations $\left(R^{2}\right)$ and modification indices (MIs), as well as theoretical justification. First, all items with non-significant regression weights were reviewed and this analysis suggested removing items 5, 10, and 29 from the scale. Second, items with low factor loadings (e.g., less than .30) were removed one at a time and the model re-run. In an effort to improve the fit, these analyses suggested removing 
items 1, 9, 17 and 34 (connection), items 7 and 15 (compassion), item 3 (mindfulness), and items 6, 1627 and 37 (transcendence).

Overall, 15 items were removed from the scale, leaving 22 items measuring four dimensions of spirituality (compassion, mindfulness, meaningful work and transcendence); see Table 1 for a summary. It should be noted that all of the items comprising the connection dimension have now been eliminated because of weak factor loadings or overall poor fit. These items likely did not contribute meaningful information to the scale because, in fact, the word "connection" does not have meaning in the Thai language. Even though the translation ensured both conceptual equivalence and text readability, the four items of the connection dimension seem to have been interpreted differently by the participants because of their unfamiliarity with the meaning of "connection." Hence, deleting the Connection dimension seems a logical step.

By eliminating the above-named items, the model achieved an acceptable fit: $\chi^{2}=312.575$, $d f=201, p=.00, C F I=.92$ and $R M S E A=.05$. It is important to note that the chi-square test is sensitive to sample size and is based on the central $l$ distribution, which assumes that the model fits perfectly in the population. Therefore, a large $\chi^{2}$ relative to degrees of freedom always requires a minor model modification (presented as a significant $\chi^{2}$ ) (Byrne 2001). As a result, even though the chi-square test was significant for this model, the other fit indices presented a satisfactory model fit. This model with 22 items fits substantially better than the model with 37 items. Correlations between each item and its underlying dimension ranged from .34 to .81 , and the r-square from .12 to .71 , thus providing evidence of adequate convergent validity. Table 1 reports coefficient alphas for the scale's underlying dimensions. Each dimension exhibits adequate reliability, although the compassion dimension is weak. Cronbach's alpha for the entire scale is .85 .

\section{Discussion and conclusion}

This paper reports the development and an initial examination of a measure of workplace spirituality. Data analysis suggested that the initial five-factor model be reduced to a four-factor model. We now define workplace spirituality as having compassion toward others, experiencing a mindful inner consciousness in the pursuit of meaningful work and that enables transcendence. The revised scale shows promise in terms of measuring spirituality in an Asian, Buddhist-centric workplace. Because the scale was developed from conceptualizations of spirituality in Western (i.e. North American) work contexts, it may also have utility in a Western work context.

Despite the promising results reported here, several important limitations need to be noted. First, the measure of spirituality would benefit from additional psychometric work. For example, even though the sample size of this study meets minimum sampling requirements (i.e. 10-20 informants for each of the 5 dimensions), additional tests with larger samples are warranted to better assess the underlying factor structure (Weston and Gore 2006).

A second issue is cultural. Workplace spirituality has not been explored in an Eastern context, yet in this research the informants are Thai so they responded to the questionnaire in the Thai language. While utilizing non-English speaking informants is both important and valuable, the questionnaire will have to be administered to employees in a Western workplace to better assess the measure's cross-cultural utility. Cross-cultural generalizations are further compromised by the fact that the data were gathered inside a company well known for its strong Buddhist tra- 
ditions. These traditions have possibly predisposed the informants to be aware of the spiritual dimension of many aspects of daily life, including work. Again, employees in a Western workplace may report different "levels" of spirituality because they are not culturally disposed toward considering their spiritual selves at work. Of course, this is an empirical issue, which can only be addressed with additional research.

Finally, research needs to be undertaken that seeks to connect spirituality with work outcomes. The premise is that a "whole" person (i.e. one who finds expression of his/her spiritual side at work) will be a "better" or more productive employee than one who is not "whole." This premise has been speculated on by many but examined by few. Thus, for HRD researchers, additional empirical work is needed to determine whether or not spirituality is, in fact, connected to work outcomes such as job satisfaction, organizational commitment, learning, effective leadership and job performance. Establishing correlates to the spirituality scale creates opportunities for HRD professionals as well. Connecting spirituality with work opens new ways to approach recruitment, training, performance evaluation and career development because it establishes the "spirit" as a dimension of human expression at least as important as the "mind" and "hands."

Acknowledgments - The authors gratefully thank S\&P Company, Bangkok Thailand for data collection cooperation.

\section{References}

Ashforth, B.E., and M.G. Pratt. 2003. Institutionalized spirituality. In Handbook of workplace spirituality and organizational performance, ed. R. A. Giacalone and C. L. Jurkiewicz, 93-107. Armonk, NY: M. E. Sharpe.

Ashmos, D. P., and D. Duchon. 2000. Spirituality at work: A conceptualization and measure. Journal of Management Inquiry 9, no. 2: 134-44.

Baer, R. A., G. T. Smith, and K. B. Allen. 2004. Assessment of mindfulness by self-report: The Kentucky inventory of mindfulness skills. Assessment 11, no. 3: 191-206.

Birbili, M. 2000. Translating from one language to another. Social Research Update. http://sru.soc.surrey. ac.uk/SRU31.html (accessed April 11, 2008).

Brown, K. W., and R. M. Ryan. 2003. The benefits of being present: Mindfulness and its role in psychological well-being. Journal of Personality and Social Psychology 84, no. 4: 822-48.

Byrne, B. M. 2001. Structural Equation Modeling with Amos: Basic concepts, applications, and programming. New Jersey: Lawrence Erlbaum Associates.

Dehler, G. E., and M. A. Welsh. 2003. The experience of work: Spirituality and the new workplace. In Handbook of workplace spirituality and organizational performance, ed. R. A. Giacalone and C. L. Jurkiewicz, 108-22. Armonk, NY: M. E. Sharpe.

Delaney, C. 2005. The spirituality scale: Development and psychometric testing of a holistic instrument to assess the human spiritual dimension. Journal of Holistic Nursing 23, no. 2: 145-67.

Delgado, C. 2005. A discussion of the concept of spirituality. Nursing Science Quarterly 18, no. 2: 157-62.

Duchon, D., and D. A. Plowman. 2005. Nurturing the spirit at work: Impact on work unit performance. The Leadership Quarterly 16: 807-33. 
Elliott, C., and S. Turnbull. 2005. Critical thinking in human resource development. New York: Routledge.

Farlex. 2007. Compassion. The Free Dictionary. http://www.thefreedictionary.com/compassion (accessed April 2, 2009).

Fenwick, T., and E. Lange. 1998. The new frontier of HRD. Canadian Journal for the Study of Adult Education 12, no. 1: 63-87.

Giacalone, R. A., and C. L. Jurkiewicz. 2003. Toward a science of workplace spirituality. In Handbook of workplace spirituality and organizational performance, ed. R. A. Giacalone and C. L. Jurkiewicz, 23-28. Armonk, NY: M. E. Sharpe.

Guillory, W. A. 1999. The living organization: "Spirituality in the workplace." Utah: Innovations.

Hambleton, R. K. 2002. Adapting achievement tests into multiple languages for international assessments. In Methodological advances in cross-national surveys of educational achievement, ed. A. C. Porter and A. Gamoran, 58-73. Washington, DC: National Academy Press.

Heaton, D. P., F. Schmidt-Wilk, and J. Travis. 2004. Constructs, methods, and measures for researching spirituality in organizations. Journal of Organizational Change Management 17, no. 1: 62-82.

Howard, S. 2002. A spiritual perspective on learning in the workplace. Journal of Managerial Psychology 17, no. 3: 230-41.

Ingersoll, R. E. 2003. Spiritual wellness in the workplace. In Handbook of workplace spirituality and organizational performance, ed. R. A. Giacalone and C. L. Jurkiewicz, 289-99. Armonk, NY: M. E. Sharpe.

Kinjerski, V. M., and B. J. Skrypnek, 2004. Defining spirit at work: Finding common ground. Journal of Organizational Change 17, no. 1: 26-42.

Kinjerski, V. M. 2006. Measuring the Intangible: Development of the Spirit at Work Scale. Paper presented at the Sixty-fifth Annual Meeting of the Academy of Management, in Atlanta, USA.

Korac-Kakabadse, N., A. Kouzmin, and A. Kakabadse. 2002. Spirituality and leadership praxis. Journal of Managerial Psychology 17, no. 3: 165-82.

Krahnke, K., R. A. Giacalone, and C. L. Jurkiewicz. 2003. Point-counterpoint: Measuring workplace spirituality. Journal of Organizational Change 16, no. 4: 396-405.

Krishnakumar, S., and C. P. Neck. 2002. The "what," "why" and "how" of spirituality in the workplace. Journal of Managerial Psychology 17, no. 3: 153-64.

Lips-Wiersma, M. 2002. Analysing the career concerns of spirituality oriented people: Lessons for contemporary organizations. Career Development International 7, no. 7: 385-97.

Mahoney, M. J., and G. M. Graci. 1999. The meanings and correlates of spirituality: Suggestions from an exploratory survey of experts. Death Studies 23: 521-28.

Maxwell, B. 1996. Translation and Cultural Adaptation of the Survey Instruments. In Third International Mathematics and Science Study (TIMSS) Technical Report, Volume 1: Design and Development, ed. M. O. Martin and D. L. Kelly, 8.1-8.10. Boston, MA: Boston College.

McCormick, D. W. 1994. Spirituality and management. Journal of Managerial Psychology 9, no. 6: 5-8.

Milliman, J., A. J. Czaplewski, and J. Ferguson. 2003. Workplace spirituality and employee work attitudes: An exploratory empirical assessment. Journal of Organizational Change Management 16, no. 4: 426-47.

Mitroff, I. I., and E. A. Denton. 1999. A spiritual audit of corporate America. San Francisco: Jossey-Bass.

Neal, J. 1997. Spirituality in management education: A guide to resources. Journal of Management Education 21, no. 1: 121-39. 
Neck, C. P., and J. F. Milliman. 1994. Thought self-leadership: Finding spiritual fulfillment in organizational life. Journal of Managerial Psychology 6: 9-16.

Petchsawang, P., and M. L. Morris. 2006. Spirituality and Leadership in Thailand. Paper presented at 2006 Academy of Human Resource Development Conference in Columbus, Ohio.

Tepper, B. J. 2003. Organizational citizenship behavior and the spiritual employee. In Handbook of workplace spirituality and organizational performance, ed. R. A. Giacalone and C. L. Jurkiewicz, 181-90. Armonk, NY: M. E. Sharpe.

Twigg, N. W., and S. Parayitam. 2006. Spirit at work: Spiritual typologies as theory builders. Journal of Organizational Culture. Communication. and Conflict 10, no. 2: 117-33.

Walach, H., N. Buchheld, V. Buttermuller, N. Kleinknecht, and S. Schmidt. 2006. Measuring mindfulness - The Freiberg mindfulness inventory (FMI). Personality and Individual Differences 40: 1543-55.

Weston, R., and P. A. Gore Jr. 2006. A brief guide to structural equation modeling. The Counseling Psychologist 34, no. 5: 719-51. 